\title{
KONSEP RUKSHAH DAN IMPLEMENTASINYA DALAM HUKUM PERNIKAHAN
}

\author{
Ahmad Jalili \\ STAIN Sultan Abdurrahman Kepulauan Riau \\ jalili_ru@yahoo.co.id
}

\begin{abstract}
ABSTRAK
Kajian ini hendak menelaah lebih jauh dari perspektif maqashid syariah terhadap rukshah dalam penikahan. Hal ini bertujaun mendapatkan gambaran jelas perihal batasan-batasan dalam implementasinya. Penelitian ini merupakan jenis penelitian kepustakaan (library research), yaitu suatu penelitian yang data-datanya berasal dari literatur-literatur yang terkait dengan obyek penelitian, kemudian dianalisis muatan isinya. Dari kajian ini menegaskan, relasi antara rukhsah dan maqashid syariah memiliki hubungan yang sangat erat. Hubungan tersebut, nampak dari tujuan utama daripada rukhsah yang diberikan oleh Syari' kepada umat manusia tidak lain adalah mewujudkan kemaslahatan bagi umat manusia itu sendiri. Hubungan antara maqashid syariah dan rukhshah memiliki kesamaan prinsip dan tujuan. Secara prinsip, yakni memberikan kemudahan dan menghilangkan kesulitan bagi setiap mukallaf, sedangkan tujuan yakni untuk memelihara kemaslahatan dan menolak kemafsadatan. Implikasi hukum yang ditimbulkan dari konsep rukhsah di bidang hukum pernikahan adalah di antaranya; (1) hukum dibolehkannya berpoligami bagi laki-laki, meskipun tidak mampu secara materi dan bersikap adil terhadap para istrinya jika memiliki uzur, seperti laki-laki hiperseksual, istrinya mandul dan sebagainya. (2) hukum diperbolehkannya memandang wanita yang dikhitbah karena adanya kebutuhan/alasan, diantaranya untuk memantapkan hati bagi si pelamar. (3) hukum dibolehkanya nikah mut'ah di zaman Rasulullah. Dengan demikian, kajian ushul fiqh perlu menjadi pertimbangan penting dalam setiap kajian fikih.
\end{abstract}

ABSTRACT: This study aims to further investigate the perspective of Maqashid sharia towards rukshah in marriage. It is to obtain a clear description of the limitations in its implementation. This study is a library research which is a study whose data comes from the literature related to the object of research, then, the content of the data are analyzed. This study has confirmed that rukhsah and maqashid sharia has a very close relationship. The relationship can be seen from the main purpose of rukshah given by Syari' to mankind that is the realization of benefit for mankind itself. The relationship between maqashid sharia and rukhshah is that both have the same principles and goals. In principle, it provides convenience and eliminates difficulties for every mukallaf, while the goal is to maintain benefit and avoid damage. The implications of law arising from the concept of rukhsah in the field of marriage law are: (1) the law fof the allowance of men to do polygamy even though they are not materially capable and are fair to their wives if they have age like hypersexual men, their wives are barren and so on; (2) the law of the allowance to see the proposed-women because of the need / reason for the men as the proposers to ensure themselves; and (3) the law of allowance to do mut'ah marriage in the Prophet era. Thus, the study of ushul fiqh needs to be mainly considered in every fiqh study.

Keywords: Concepts, Rukhsah and Rulings of Marriage

\section{PENDAHULUAN}

Perdebatan para pakar ushul terkait diskursus term rukhshoh sangat menarik untuk ditelaah lebih mendalam. Karena meskipun di antara ushuliyyun terdapat kesamaan dalam memahami rukhshoh secara umum, tetapi secara teoritis terjadi perbedaan mendasar dalam merumuskan konsep rukhshoh dalam berbagai perspektifnya. Perbedaan itu, lebih disebabkan karena rukhshoh memang memiliki makna yang multi-interpretatif. Di pihak lain, rukhsah juga seringkali dijadikan 
dalil dalam melegalkan sesuatu yang diharamkan, karena sudah mengarah kepada tatabu' ar-rukhas (mencari-cari kemudahan dengan motif memenuhi hawa nafsunya).

Pembahasan mengenai term rukhshoh dalam kajian fikih dan ushulnya memang telah dilakukan oleh para sarjana Muslim klasik maupun kontemporer. Di antara literatur-literatur klasik di bidang ushul fikih seperti: Al-Mustashfa Min Ilmil Ushul karya Imam Al-Ghazali, Al-Ibkam Fi Ushulil Abkam karya Abu Hasan Al-Amidy, Al-Muwafaqot fi Ushul al-Fiqh karya Imam as-Syathibi, Taqwimul Adillah Fi Ushulil Abkam karya AdDabusi, Kitab Fi Ushulil Fiqh karya AlLamisyi, Al Taudlib li matn Al Tanqih fii Ushul Fiqh, karya Imam Al Qodli Shodr Syari'at Abdullah bin Mas'ud Al Mahbubi, dan kitab lain yang ada kaitanya dengan pembahasan ini, baik secara etimologis maupun secara terminologis.

Syekh Hudhari Biek menjelaskan dalam kitabnya, bahwa rukhshoh dalam syara' mempunyai empat esensi. ${ }^{1}$ Pertama, suatu hukum yang dikecualikan dalam sekawanan hukum-hukum lainnya yang bersifat universal yang menunjukkan larangan secara mutlak. Seperti hukum akad salam, musaqoh dan lainnya yang merupakan pengecualian dari kaidah-kaidah dasar dalam akad atau transaksi. Kedua, hukum yang dihapuskan karena hukum-hukum tersebut memberatkan kepada umat Nabi Muhammad SAW, yang dulu pernah disyariatkan kepada umat-umat terdahulu, seperti cara mensucikan najis, di zaman Nabi Musa as. pakaian yang terkena najis harus dipotong, tetapi umat Nabi Muhammad baju yang terkena najis dapat disucikan dengan membasuhnya dengan air yang suci. Ketiga, hukum-hukum syariat yang memberikan kelonggaran secara mutlak dalam mencapai tujuan kebahagian seorang mukallaf, seperti dalam dibolehkannya poligami. Keempat, hukum yang disyariatkan karena adanya udzur yang memberatkan, dan hukum tersebut sebagai pengecualian dari hukum-hukum dasar yang bersifat universal karena hanya bersifat temporer dan

\footnotetext{
1 Lihat, Hudhari Biek, Ushul Fiqh,
} (Kairo: Dar al-Kutub al-Arabiyah, 1999), hlm. 67. kondisional, contohnya dibolehkannya mengqoshar dan menjama' shalat ketika dalam perjalanan, diperbolehkan tayamum sebagai ganti wudhu.

Gambaran di atas telah mempertegas bahwa pembahasan term rukbshoh, banyak disebutkan oleh para ulama. Namun, seringkali pembahasan tersebut dalam dalam porsi yang minimalis. Artinya, pembahasan rukhshoh hanya menjadi bagian kecil dari seluruh pembahasan dalam kajian ushul fikih. Menurut penulis, belum ditemukan literatur ushul fikih klasik yang lebih spesifik membahas konsep rukbshoh secara metodologis dan aplikatif yang lebih komprehensif. Hal demikian ini membuat kajian tentangnya menjadi terbuka lebar, apalagi bila dikaji secara tersebut lebih spesifik dalam bidang pernikahan.

Kajian fikih munakahat juga terdapat beberapa keringan atau rukshah. Bahkan, beberapa mazhab berbeda pendapat dalam melihat illat hukum terhadap rukshah dalam pernikahan itu sendiri. Misalnya, dalam kasus nikah tanpa wali dan saksi yang berdalih mengikuti mazhab Hanafi dan Maliki sekaligus. Padahal, meskipun dalam mazhab Hanafi dibolehkan nikah tanpa wali, tetapi Imam Hanafi menjadikan walimah sebagai media pemberitahuan kepada orang lain menjadi syarat sahnya nikah. Demikian halnya, dalam mazhab Maliki meskipun saksi tidak menjadi rukun nikah, tetapi Imam Malik menjadikan wali nikah menjadi rukun nikah dan tidak sah tanpanya. Dengan demikian, nikah tanpa wali dan saksi, secara syar'i tidak sah, baik menurut mazhab Hanafi maupun Maliki. Bermazhab seperti ini dalam term ushul fikih disebut talfíq.

Kajian ini hendak menelaah lebih jauh dari perspektif maqashid syariah terhadap rukshah dalam penikahan. Hal ini bertujaun mendapatkan gambaran jelas perihal batasan-batasan dalam implementasinya. Maka pertanyaan penting dalam penelitian ini ialah bagaimana hubungan konsep rukhsah dengan maqashid syariah dan implikasinya dalam pernikahan?

Penelitian ini merupakan penelitian deskriptif kualitatif, yaitu penelitian yang 
berusaha mengungkap keadaan yang bersifat alamiah secara holistik. Masalah dan fakta akan digambarkan secara deskriptif, kemudian dianalisis untuk memperoleh gambaran utuh tentang permasalahanpermasalahan yang akan diteliti. ${ }^{2}$ Penelitian ini merupakan jenis penelitian kepustakaan (library research), yaitu suatu penelitian yang data-datanya berasal dari literatur-literatur yang terkait dengan obyek penelitian, kemudian dianalisis muatan isinya. Terkait hal tersebut, dalam penelitian ini, akan dihimpun data yang berhubungan dengan konsep rukhshah serta contohnya.

\section{Relasi Rukhshah dan Maqashid Syariah}

Menurut As-Subki rukhsah adalah hukum yang berubah kepada kemudahan dan keringan sebab adanya uzur serta tetapnya hukum asal bagi yang tidak mengalami uzur, seperti memakan bangkai bagi orang yang mengalami keadaan darurat. ${ }^{3}$ Dalam kitab arRukhos as-Syar'iyyah: abkamuba wa dhawabithiba disebutkan sebab-sebab seorang itu akan mendapatkan keringan atau rukhsah ketika mengalamai kondisi-kondisi berikut: addharurah (keadaan darurat), al-masyaqqah (kondisi sulit), as-safar (kondisi bepergian), alikrah (kondisi dipaksa), al-maradh (kondisi sakit), an-nisyan (kondisi lupa), al-khata (kondisi keliru), al-jabl (kondisi tidak tahu), umum al-balwa (kesulitan yang umum) dan annaqsh (kondisi kekurangan). ${ }^{4}$ Dengan demikian, rukhsah adalah keringanan hukum sebab ada hal menghalanginya.

Sedangkan maqasid syariah, menurut Wahbah al Zuhaili, berarti nilai-nilai dan sasaran syara' yang tersirat dalam segenap atau bagian terbesar dari hukum-hukumnya. Nilai-nilai dan sasaran-sasaran itu dipandang sebagai tujuan dan rahasia syariah, yang ditetapkan oleh al-Syari dalam setiap

${ }^{2}$ M. Ali Sayuti, Metode Penelitian Agama: Pendekatan Teori dan Praktek, (Jakarta: PT. RajaGrafindo Persada, 2002), h. 47

3 Az-Zarkasyi, Tasnif al-Masami' bi Jam'i alJawami' (tt.: Muassasah Qardubah, 1999), h. 95.

4 Usamah Muhammad bin Muhammad asSollabi, ar-Rukhos as-Syar'iyyah: Abkamuba wa Dhawabithuha, (Iskandaria: Dar- al-Iman, 2002), h. 113. ketentuan hukum. ${ }^{5}$ Dilihat dari sudut tujuan Tuhan, maqasid syariah mengandung empat aspek, yaitu: ${ }^{6}$ pertama, Tujuan awal dari Syari' menetapkan syariah yaitu kemashlahatan manusia di dunia dan akhirat. Kedua, penetapan syariah sebagai sesuatu yang harus dipahami. Ketiga, penetapan syariah sebagai hukum taklifi yang harus dilaksanakan. Keempat, penetapan syariah guna membawa manusia ke bawah lindungan hukum. ${ }^{7}$

Inti dari maqashid syariah adalah dalam rangka mewujudkan kebaikan sekaligus menghindarkan keburukan atau untuk menarik manfaat dan menolak madharat. Abu Ishaq al-Syatibi melaporkan hasil penelitian para ulama terhadap ayat-ayat AlQur'an dan Sunnah Rasulullah bahwa hukum-hukum disyariatkan Allah untuk mewujudkan kemaslahatan umat manusia, baik di dunia maupun akhirat kelak. Kemaslahatan yang akan diwujudkan itu menurut as-Syatibi, terbagi menjadi tiga tingkatan, yaitu tingkatan kebutuhan dharuriyat, kebutuhan bajiyat, dan kebutuhan tahsiniyat. ${ }^{8}$

Gambaran di atas mempertegas bahwa korelasi rukhsah dan maqasid syariah memiliki hubungan yang tidak terpisah. Korelasi ini termanifestasi pada hubungan keduanya di dalam hal menjaga dan memelihara kemaslahatan dan keringanan serta kemudahan bagi mukallaf dalam menjalankan syaraiat Islam. Hal ini juga dapat tercermin dari definisi kedua term rukhsah dan maqasid syariah baik dari segi etimologi maupun terminologi.

Tujuan dari pensyariatan hukumhukum adalah menjaga kemaslahatan manusia dan memberikan keringanan dan kemudahan serta menolak kesulitan-kesulitan yang dihadapi manusia. Dari sini, maka hubungan antara maqhasid syariah dan rukhs\}ah meliputi: pertama, keduanya

5 Wahbah az-Zuhaili, Ushul Fiqh Islamy, (Damaskus: Dar al Fikr, 1986), juz 2 h. 225

6 Nasrun Rusli, Konsep Ijtihad Al Syankani: Relevansinya bagi Pembaruan Hukum Islam di Indonesia, (Jakarta: Logos, 1999), h. 43.

7 As-Syatibi, al-Muwafaqat.....vol. 2, h. 4

8 Abu Ishaq al-Syatibi, Al-Muwafaqat, (Bairut: Darul Ma'rifah , 1997), jilid 1-2, h. 324 
memiliki prinsip yang sama, yakni memberikan kemudahan dan menghilangkan kesulitan mukallaf. Kedua, keduanya memiliki tujuan untuk memelihara kemaslahatan dan menolak kemafsadatan.

\section{Rukshah dan Implementasinya dalam Hukum Pernikahan}

\section{Telaah Defenisi Rukshah}

Kalangan Hanafiyah seperti alBazdawi berpendapat rukhsab adalah keringanan yang diberikan kepada mukallaf disebabkan adanya uz|ur, yang mana atas hukum perbuatan tersebut sebenarnya diharamkan bagi orang yang tidak memiliki uz | ur.

Mazhab Hanafiyah mensyaratkan seseorang untuk mendapatkan rukhsah bila ia mendapati pada dirinya suatu uz $\mid$ ur tertentu. Sementara dalam pandangan An-Namlah, uz | ur ini hanya berhubungan dengan kondisi darurat, masyaqqah dan hajat. Dengan demikian, rukhs $\}$ ah ini hanya berlaku bagi orang yang dalam kondisi mendesak (darurat), kesulitan (masyaqqah) dan sangat membutuhkan (hajat).

Menurut pandangan pandangan AsSyatibi rukhsah adalah hukum yang disyariatkan sebab adanya uz|ur yang sangat berat yang merupakan pengecualian dari hukum asal yang bersifat umum (kulli) yang menunjukkan larangan dan Rukhs\}ah tersebut hanya terbatas bagi orang-orang yang membutuhkan terhadap sesuatu secara mendesak. $^{10}$

Menurut penulis definisi rukhsah yang lebih sederhana tetapi komprehensif (jami' mani') adalah hukum yang ditetapkan dan bertentangan dengan sesuatu yang ditunjukkan oleh dalil sebab adanya uz|ur. Adapun yang dimaksud dengan bertentangan dengan dalil di sini, secara tidak langsung mengisyaratkan bahwa rukhsah harus ditetapkan berdasarkan dalil.

\footnotetext{
${ }^{9}$ An-Namlah, ar-Rukhas as-Syar'iyyah.....h. 52.

10 As-Syathibi, Al-Muwafaqat.....h. 301.
}

\section{Implementasi Rukshah dalam Hukum Pernikahan}

Konsep rukhsah dalam hukum Islam yang berdampak pada pengembangan hukum Islam. Karena dengan adanya rukhsah berarti dalam satu masalah memiliki dua sisi hukum yang berbeda, yakni hukum normal bagi mukallaf yang tidak memiliki uzur dan hukum darurat bagi yang memiliki uzur. Oleh karenanya pula, pada sub bab ini penulis uraikan implementasi rukhsah dalam hukum pernikahan sebagai berikut.

\section{a. Rukhsah bai Laki-Laki untuk Berpoligami}

Menurut Sayyid Quthb bahwa poligami merupakan rukhsah (keringanan). Oleh karena itu, ia hanya bisa dilakukan dalam keadaan darurat dan benar-benar mendesak. Kebolehan itu, menurutnya, masih disyaratkan bagi laki-laki yang mampu berbuat adil terhadap istri-istrinya. Keadilan yang dimaksud di sini adalah dalam hal nafkah, muamalah, pergaulan dan pembagian malam. Bagi laki-laki (suami) yang tidak mampu adil, menurut dia diharuskan cukup satu saja. Dan bagi yang mampu berbuat adil terhadap istri-istrinya, diperbolehkan melakukan poligami dengan jumlah istri dalam satu waktu maksimal empat orang. ${ }^{11}$

Poligami merupakan solusi yang ditawarkan bagi laki-laki yang memiliki keadaan yang mendesak untuk berpoligami, beristeri lebih dari satu. Kebolehan di sini,

${ }^{11} \mathrm{Al}-\mathrm{Maragi}$ dalam kasus ini mengatakan bahwa kebolehan berpoligami merupakan kebolehan yang dipersulit dan diperketat. Orang melakukan poligami hanya dalam kondisi darurat dan benar-benar membutuhkannya. Beberapa alasan yang membolehkan poligami menurutnya adalah : istri mandul, sementara itu keduanya stau salah satunya mengharapkan keturunan, si suami mempunyai kemampuan seks yang tinggi sementara istri tidak mampu melayani sesuai dengan kebutuhannya, si suami mempunyai harta yang banyak untuk membiayai segala kepentingan keluarga, mulai dari kepentingan istri hingga kepentingan anak, jumlah perempuan melebihi dari jumlah pria (yang ini bisa terjadi karna adanya perang), banyaknya janda dan anak yatim yang perlu dilindungi, jumlah penduduk yang ternyata memang faktanya perempuan jauh lebih banyak ketimbang laki-laki. Lihat, al-Maraghi, Tafsir al-Maragi, juz IV, h. 183-184. 
menurut para pakar tafsir disyaratkan bagi suami dibolehkan berpoligami jika ia dapat berlaku adil. ${ }^{12}$ Sebaliknya, jika suami tidak mampu berlaku adil, maka haram baginya untuk berpoligami kecuali dalam keadaan darurat atau mendesak, seperti istri dalam kondisi mandul, sakit, suami mengalami hiperseksual dan sebagainya. Oleh sebab itu, berubahnya hukum haram menjadi boleh tanpa adanya keadilan dari pihak suami inilah yang termasuk rukhsah. ${ }^{13}$

\section{b. Rukhsah Memandang Wajah Wanita Dikbitbah}

Pada dasarnya, syariat mengharamkan memandang wajah wanita bukan mahram dengan pandangan yang berdampak kepada timbulnya fitnah atau dalam bahasa fikih disebut an-nazar bi at-talazu\%. Meskipun demikian, hukum Islam bukan ajaran yang kaku, tetapi sangat fleksibel. Itu sebabnya, larangan memandang wajah wanita bukan

12 Keadilan menurut Qurash Shihab, sebagaimana yang disebutkan dalam tafsir al-Mis\}bah, mengatakan bahwa pada ayat ketiga surah an-Nisa', sang suami diperintahkan untuk berlaju adil diantara istri-istrinya, dan pada ayat ke-129 ini Allah menegaskan bahwa keadilan yang dimaksud bukanlah keadilan dalam hal cinta. Karena cinta atau suka pun dapat dibagi. Suka yang lahir atas dorongan perasaan dan suka yang atas dorongan akal. Obat yang pahit, tidak dsukai oleh siapapun, ini berdastkan perasaan setiap orang. Tetapi obat yang sama akan di sukai dicari dan diminum karena akal si sakit mendorongnya menyukai obat itu walau ia pahit. Demikian suka atau cinta dapat berbeda. Yang tidak mungkin dapat diwujudkan disini adalah keadilan dalam cinta atau suka berdasarkan perasaan, sedang suka yang berdasarkan akal, dapat diusahakan manusia, yakni memperlakukan istri dengan baik, membiasakan diri debgan kekurangan-kekurangannya, memandang semua aspek yang ada padanya, bukan hanya aspek keburukannya. Inilah yang dimaksud dengan "Janganlab kamu terlalu cenderung ( kepada orang yang kamu cintai), danjangan juga terlalu cenderung mengabaikan yang kamu kurang cintai. Lihat, Quraish Shihab, Tafsir al-Misbah, (Jakarta: Lentera Hati, 2002), vol.2, h. 607

${ }^{13}$ Menurut penulis, kebolehan berpoligami ketika suami mampu bersikap adil, bukanlah suatu rukhs \}ah. Karena pada dasarnya, kebolehan itu berdasarkan petunjuk langsung dari teks, atau dengan kata lain bahwa poligami atau tidak, tergantung terhadap kemampuan seoarang laki-laki (suami) dalam hal bersikap adil terhadap para istri-istrinya. mahram ini berlaku bagi kaum laki-laki yang tidak memiliki keperluan terhadap wanita tersebut. Karena dalam Islam membolehkan memandang lawan jenis bagi yang memiliki hajat dalam beberapa keperluan. Misalnya, seorang wanita yang menjadi saksi dalam pengadilan, maka seoarang hakim boleh melihat wajahnya. Seorang dokter laki-laki dapat memandang wajahnya wanita untuk keperluan pengobatan. Demikian pula, dalam kasus melamar (khitbah) wanita bahwa seorang laki-laki diperbolehkan memandang wajah dan telapak tangan wanita tersebut yang hendak dinikaihinya. Begitu juga sebaliknya, wanita dibolehkan memandang wajah.

Dengan demikian, hukum azimahnya dalam kasus ini adalah diharamnya laki-laki untuk memandang perempuan bukan mahramnya secara talaz:udz yakni pandangan yang akan menimbulkan fitnah. Namun, karena adanya kebutuhan syar'i, maka larangan tersebut berubah menjadi kebolehan. Hukum bolehnya memandang wajah wanita bagi laki-laki pelamar wanita inilah yang disebut rukhsah. Yakni perubahan hukum dari yang diharamkan menjadi dibolehkan sebab adanya uzur yaitu berupa bajat (kebutuhan) yang dilegitimasi syariat dalam rangka memantapkan hati calon suami atas calon istrinya dengan melihat wajah dan telapak tangannya sebagi simbol kecantikan dan keluwesan wanita yang hendak dinikahi tersebut.

\section{c. Rukhsah Nikah Mut'ah pada Awal Islam}

Nikah mut'ah, pada awal Islam saat kondisi darurat hukumnya diperbolehkan, kemudian baru datang nas\}-nas\} yang melarangnya hingga hari Kiamat. Di antara dalil-dalil kebolehan nikah mut'ah di awal Islam yaitu:

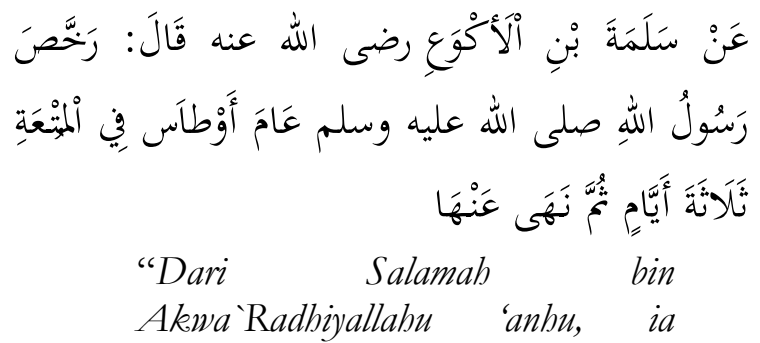


berkata: "Rasulullah Shallallahu 'alaibi wa sallam telah memberikan keringanan dalam mut'ah selama tiga hari pada masa perang Awtas (juga dikenal dengan perang Hunain), kemudian beliau melarang kami." "14

Hadis di atas, menunjukkan bahwa nikah mut'ah pada awal-awal Islam merupakan keringanan atau rukhs $\}$ ah bagi umat Islam yang memiliki kondisi-kondisi tertentu yang mendesak. Oleh karenanya, Rasulullah saw memberikan kemudahan dengan diperbolehkannya nikah mut'ah bagi para sahabat ketika itu.

Meskipun demikian, hukum kebolehan nikah mut'ah tidak berlaku selamanya. Artinya hanya bersifat temporer dan sebelum keputusan akhir dari Rasulullah bahwa hukum nikah mut'ah menjadi haram. Hal ini berdasarkan hadis Nabi saw. yang diriwayatkan Muslim, : dari Muhammad bin Ali (yang dikenal dengan sebutan Muhammad bin Hanafiah), bahwa ayahnya Ali (bin Abu Thalib) berkata kepada Ibnu Abbas ra. : "Sesungguhnya Nabi saw. melarang mut'ah dan daging keledai pada masa Khaibar." 15

\section{${ }^{14} \mathrm{HR}$ Muslim, 9/157, (1405).}

15Riwayat pengharaman nikah mut'ah pada penaklukan kota Mekkah, yaitu riwayat dari Rabi' bin Sabrah Radhiyallahu 'anhu, bahwa ayahnya berperang bersama Rasulullah Shallallahu alaihi wa sallam pada penaklukkan kota Mekkah. Kami tinggal lima belas hari. Kemudian, oleh Rasulullah Shallallahu 'alaihi wa sallam kami diperbolehkan untuk mut'ah. Akupun keluar bersama seseorang dari kabilahku. (Kebetulan) aku mempunyai sedikit ketampanan, sedangkan kerabatku tersebut lebih mendekati jelek. Setiap kami membawa sal, salku jelek, sedangkan sal anak pamanku tersebut baru dan mengkilap. Ketika kami sampai di kaki Mekkah atau di puncaknya, kami bertemu dengan seorang gadis perawan, panjang lehernya semampai. Kami berkata,"Apakah engkau mau bermut'ah dengan salah seorang dari kami?" Dia berkata,"Dengan apa kalian bayar?" Maka setiap kami membentangkan salnya. Lalu wanita itu melihat kami, dan sahabatku itu melihat ketiaknya dan berkata: "Sesungguhnya sal dia jelek, sedangkan salku baru, mengkilap". Dia berucap,"Salnya tidak apa-apa," dua kali atau tiga. Lalu aku melakukan mut'ah dengannya. Belum usai aku keluar dari Mekkah, kiranya Rasulullah Shallallahu 'alaihi wa sallam telah mengharamkannya. HR Muslim, 9/158, (1406).

\section{d. Rukbsah Suami Memukul Istri yang Nusyuz.}

Dalam menjalin hubungan suami istri memang tidak selamanya mulus. Bahkan banyak terkadang di antara mereka dipenuhi dengan pertengkaran dan percekcokan yang tidak berkesudahan. Rumah tangga menjadi hancur berantakan, tidak memunculkan kebahagian apapun. Seringkali setiap terjadi pertengkaran istri selalu di pihak yang dipersalahkan. Akan tetapi, bila benar istri yang menyebabkan ketidakharmonisan itu, karena ia melakukan hal-hal yang dapat mengabaikan kewajibannya sebagai istri, maka sikap mengabaikan kewajiban sebagai istri ini disebut dengan nusyuz.

Perintah dalam al-Quran “وَّاضْرِبُوهُنَّ dalam

konteks ini bukannya serta merta memberi izin kepada suami untuk memukul istrinya secara mutlak.

Pemukulan diperbolehkan bagi suami setelah melalui dua tahap yaitu menasihati istri $^{16}$. Jika dengan menasihati istri tetap nusyuz (membangkang), maka tahap selanjutnya adalah pisah ranjang. Jika dengan pisah ranjang istri masih tetap nusyur, maka suami boleh memukulnya. Pemukulan ini harus meliputi syarat-syarat sebagai berikut: pertama, pemukulan tidak boleh diarahkan ke wajah. Kedua, pemukulan tidak sampai meninggalkan bekas, yakni menggunakan alat seringan-ringannya misalnya dengan menggunakan siwak, sapu tangan, dan sejenisnya. Ketiga, pemukulan dalam rangka mendidik, bukan yang bersifat dendam dan ingin menang sendiri. Keempat, pemukulan hanya dilakukan sepanjang memberikan efek

${ }^{16}$ Syaikh Muhammad Thahir Ibnu 'Asyur menyatakan, wewenang memukul istri diberikan pada suami demi kebaikan kehidupan rumah tangga. Pemukulan diserahkan pada suami karena ia yang mempunyai kewajiban untuk mendidik istrinya. Ketika pemukulan tidak bisa lagi efektif untuk memulihkan kehidupan rumah tangga yang baik, maka wewenang itu bisa dicabut. Lihat, Faqihuddin Abdul Kodir, dkk. Fiqh Anti Trafiking: Jawaban atas Berbagai Kasus Kejahatan Perdagangan Manusia Dalam Perspektif Hukum Islam, (Cirebon: Fahmina Institute, 2006), h. 111. 
manfaat bagi keutuhan dan keharmonisan relasi suami istri. ${ }^{17}$

Dengan demikian, kebolehan suami memukul istri yang telah melakukan nusyuz merupakan rukhs $\}$ ah dalam rangka memberikan pendidikan kepada sang istri. Adapun sebab kebolehannya adalah adanya kebutuhan (hajat) untuk menciptakan keharmonisan yang diidamkan melalui pemukulan yang tidak melukai. Tentunya, dengan tahapan-tahapan yang telah dijelaskan sebalumnya yakni tidak serta merta memukul istrinya tanpa dinasehati terlebih dahulu. Sebaliknya, jika dengan pemukulan itu justru akan menimbulkan mafsadat yang lebih besar, maka suami selamanya tidak diperbolehkan memukul istrinya.

\section{PENUTUP}

Berdasarkan pembahasan yang telah diuraikan di bab-bab sebelumnya, maka penelitian tentang konsep rukhsah dan implikasinya dalam hukum pernikahan dapat disimpulkan beberapa hal. Pertama, para ushuliyyun berbeda pendapat dalam menguraikan konsep rukhsah. Meskipun demikian, dapat ditarik titik temu bahwa rukhsah menurut para pakar ushul yaitu suatu perubahan hukum disebabkan adanya uzur (halangan). Adapun uzur secara umum yang dapat menyebabkan seseorang mendapat rukhsah sebagai berikut: addharurah (keadaan darurat), al-masyaqqah (kondisi sulit), as-safar (kondisi bepergian), alikrah (kondisi dipaksa), al-maradh (kondisi sakit), an-nisyan (kondisi lupa), al-khata (kondisi keliru), al-jabl (kondisi tidak tahu), umum al-balwa (kesulitan yang umum) dan annaqsh (kondisi kekurangan).

Kedua, relasi antara rukhsah dan maqashid syariah memiliki hubungan yang sangat erat. Hubungan tersebut, nampak dari tujuan utama daripada rukhsah yang diberikan oleh Syar' kepada umat manusia tidak lain adalah mewujudkan kemaslahatan bagi umat manusia itu sendiri. Selain itu, dengan adanya rukhsah ini manusia dapat

17 Husein Muhammad, Islam Agama Ramah Perempuan: Pembelaan Kiai Pesantren, (Yogyakarta: LkiS, 2007), h. 242 terhindar dari segala kesulitan-kesulitan yang mungkin dihadapi oleh setiap manusia dalam kondisi-kondisi darurat tertentu. Lebih dari itu, relasi keduanya juga dapat tercermin dari definisi kedua term rukhshah dan maqasid syariah, baik dari segi etimologi maupun terminologi. Dengan demikian, hubungan antara maqashid syariah dan rukhshah meliputi: pertama, keduanya memiliki prinsip yang sama, yakni memberikan kemudahan dan menghilangkan kesulitan bagi setiap mukallaf. Kedua, keduanya memiliki tujuan untuk memelihara kemaslahatan dan menolak kemafsadatan.

Ketiga, implikasi hukum yang ditimbulkan dari konsep rukhsah di bidang hukum pernikahan adalah di antaranya: (1) hukum dibolehkannya berpoligami bagi lakilaki, meskipun tidak mampu secara materi dan bersikap adil terhadap para istrinya jika memiliki uzur, seperti laki-laki hiperseksual, istrinya mandul dan sebagainya. (2) hukum diperbolehkannya memandang wanita yang dikhitbah karena adanya kebutuhan/alasan, diantaranya untuk memantapkan hati bagi si pelamar. (3) hukum dibolehkanya nikah mut'ah di zaman Rasulullah.

Berdasarkan simpulan di atas, maka penulis perlu memberikan saran bagi kalangan akademisi kampus. Pertama, Kajian tentang rukhsah dan implikasinya terhadap hukum Islam sangat urgen dalam rangka pengembangan hukum. Pada penelitian ini, hanya difokuskan pada implikasi konsep rukhsah terhadap kajian fiqh munakahat atau hukum pernikahan. Keterbatasan ini, nantinya diharapkan dapat ditindaklanjuti dengan diadakannya penelitian lanjutan dengan tema yang sama tetapi dengan pendekatan yang mungkin berbeda. Kedua, urgensitas penelitian model kajian ushul fiqh sangat penting kiranya untuk dilanjutkan penelitian semacam ini dengan memfokuskan pada implikasi rukhsah terhadap bidang kajian bab fikih khususnya pada bab fiqh jinayat dan figh muamalat. Karena penelitian tentang seputar rukhsah, umumnya banyak hanya mengaitkan dengan bab fiqh ibadat saja. Dengan demikian, nantinya diharapkan kajian rukhsah dan implikasinya terhadap hukum 
Islam menjadi lebih komprehensif dari berbagai bab-bab fiqh, mulai ibadat, muamalat, munakahat dan jinayat.

\section{DAFTAR PUSTAKA}

Abdulah, Muhammad Husain, Al-Wadih fi Us\}ul al-Figh, (Kairo: Dar as-Salam, 1995),

An-Namlah, Abdul Karim bin Ali, $A r$ Rukbas\} As-Syar'iyyah wa isbatuba Bil Qiyas (Riyadh: Maktabah Ar-Rasyd, 1990).

Az-Zarkasyi, Tasnif al-Masami' bi Jam'i alJawami' (tt.: Muassasah Qardubah, 1999)

Az-Zuhaili, Wahbah, usul al-Figh al-Islami, (Damaskus: Dar al-Fikr, 2005).

Biek, Muhammad Hudhari, usul Fiqh, (Kairo: Dar al-Kutub al-Arabiyah, 1999).

Husein Muhammad, Islam Agama Ramah Perempuan: Pembelaan Kiai Pesantren, (Yogyakarta: LkiS, 2007),
Ibn Rusyd, Bidayah al-Mujtabid wa Nibayah Muqtashid (Kairo: Maktabah Ibn Taimiyah, 1415).

Izz ibnu Abdul as-Salam - Qawa'id al-Abkam (Beirut: Dar al-Fikr, 2001).

Khallaf, Abd. Wahab, Ilmu usul Figh, (Dar AlQalam, Kuwait, tt.).

Salim, Muhammad Husni Ibrahim, ar-Rukhas wa asbab at-Tarakhus\} fi al-Figh alIslamy, (Kairo: Dar at-tabaah alMuhammadiyah, 1987),

Shihab, Quraish, Tafsir al-Misbah, (Jakarta: Lentera Hati, 2002),

Rusli, Nasrun, Konsep Ijtibad Al Syaukani: Relevansinya bagi Pembaruan Hukum Islam di Indonesia, Jakarta: Logos, 1999)

Usamah Muhammad bin Muhammad as-Sollabi, ar-Rukbos as-Syar'iyyah: Abkamuba wa Dhawabithuba, (Iskandaria: Dar- al-Iman, 2002. 